\title{
Yeast microbiota of free-ranging amphibians and reptiles from Caatinga biome in Ceará State, Northeast Brazil: High pathogenic potential of Candida famata
}

\author{
Débora de Souza Collares Maia Castelo-Branco ${ }^{1}$ (D) Renan Vasconcelos da Graça-Filho ${ }^{2}$ (D) \\ Jonathas Sales de Oliveira ${ }^{1}$ (D) Maria Gleiciane da Rocha $^{2}$ (D) Géssica dos Santos Araújo $^{2}$ (D) \\ Manoel Paiva de Araújo Neto ${ }^{3}$ (i) Rossana de Aguiar Cordeiro ${ }^{1}$ (i) Waldemiro de Aquino Pereira-Neto ${ }^{1}$ (i)

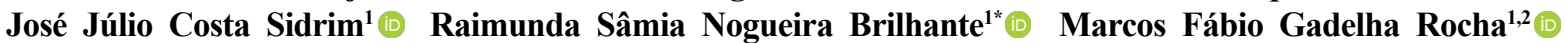

${ }^{1}$ Centro Especializado em Micologia Médica, Programa de Pós-graduação em Microbiologia Médica, Departamento de Patologia e Medicina Legal, Universidade Federal do Ceará (UFC), Fortaleza, CE, Brasil. E-mail: brilhante@ufc.br. "Corresponding author.

${ }^{2}$ Programa de Pós-graduação em Ciências Veterinárias, Faculdade de Veterinária, Universidade Estadual do Ceará (UECE), Fortaleza, CE, Brasil.

${ }^{3}$ Laboratório de Biologia Ambiental e Microbiologia, Curso de Ciências Biológicas, Instituto Federal de Educação, Ciência e Tecnologia do Ceará (IFCE), Acaraú, CE, Brasil.

ABSTRACT: Studies on the fungal microbiota of reptiles and amphibians are necessary to better understand of host-microbe interactions and the establishment of fungal disease in these animals. However, these studies are limited. The present researchidentified yeasts from free-ranging reptiles and amphibians from the Caatinga biome andevaluated the virulence factors production, the antifungal susceptibility in planktonic and biofilm growth and the pathogenicity of Candida famata isolates. Twenty-nine isolates of the genera Candida, Cryptococcus and Rhodotorula were identified by phenotypic and/or molecular methods and production of hydrolytic enzymes in vitro by these genera of fungi was evaluated. In addition, susceptibility of planktonic cells and biofilms to azoles and amphotericin $B$ was evaluated. The pathogenicity of C. famata, the most prevalent yeast species isolated, was evaluated using Caenorhabditis elegans model. C. famata was the most prevalent yeast in amphibian and reptilian microbiota. Phospholipase and protease production was observed in 18/29 and 11/29 of the yeast isolates, respectively, while $100 \%$ formed biofilms. Itraconazole presented high minimal inhibitory concentrations against C. famata and C. tropicalis. Amphotericin B reduced the biomass and metabolic activity of biofilms. C. famata induced the mortality of C. elegans. In conclusion, reptiles and amphibians are colonized by yeasts capable of producing important virulence factors, especially by Candida spp. that present low susceptibility to azoles which may result from imbalances in ecosystem. Finally, C. famata isolated from these animals presented high pathogenicity, showing the importance of the study of reptile and amphibians fungal microbiota.

Key words: herpetofauna, yeasts, antifungal, virulence, pathogenicity.

Leveduras da microbiota de anfíbios e répteis do bioma Caatinga no Ceará, Nordeste do Brasil: alto potencial patogênico de Candida famata

RESUMO: Estudos sobre a microbiota fúngica de répteis e anfibios são necessários para melhor compreender as interações hospedeiromicrorganismo e o estabelecimento de doenças fúngicas nesses animais. No entanto, esses estudos são limitados. $O$ objetivo da presente pesquisa foi identificar leveduras isoladas de répteis e anfibios do bioma Caatinga e avaliar a produção de fatores de virulência, a sensibilidade a antifúngicos no crescimento planctônico e de biofilme e a patogenicidade de Candida famata. Vinte e nove isolados dos gêneros Candida, Cryptococcus e Rhodotorula foram identificados por métodos fenotípicos elou moleculares e a produção de enzimas hidrolíticas in vitro por esses gêneros de fungos foi avaliada. Além disso, foi avaliada a suscetibilidade de células planctônicas e biofilmes a azólicos e anfotericina B. A patogenicidade de C. famata, a espécie de levedura isolada mais prevalente, foi avaliada usando Caenorhabditis elegans. C. famata foi a levedura mais prevalente na microbiota de anfibios e répteis. A produção de fosfolipase e protease foi observada em 18/29 e 11/29 dos isolados de levedura, respectivamente, enquanto $100 \%$ formaram biofilmes. O itraconazol apresentou altas concentrações inibitórias mínimas contra $C$. famata e C. tropicalis. A anfotericina B reduziu a biomassa e atividade metabólica dos biofilmes. C. famata induziu a mortalidade de C. elegans. Em conclusão, répteis e anfíbios são colonizados por leveduras capazes de produzir importantes fatores de virulência, especialmente por cepas de Candida spp. que apresentam baixa suscetibilidade a azólicos que podem resultar de desequilibrio no ecossistema. Por fim, C. famata isolados desses animais apresentaram alta patogenicidade, mostrando a importância do estudo da microbiota fúngica de répteis e anfíbios. Palavras-chave: herpetofauna, leveduras, antifúngico, virulência, patogenicidade.

\section{INTRODUCTION}

Herpetology is the strand of zoology that studies amphibians and reptiles, by researches on their evolution, biology, behavior, husbandry, among others (BORGES-LEITE; RODRIGUES; BORGESNOJOSA, 2014). As part of the studies focusing on the understanding of the biology and health of these animals, in free-ranging and captive conditions, researches aiming the characterization of their 
bacterial (NOWAKIEWICZ et al., 2015; VEGAMANRIQUEZ et al., 2018; CARDOSO-BRITO et al., 2019) and fungal (BENITES et al., 2013; BRILHANTE et al., 2015a; SVEDESE et al., 2017) microbibota have been performed. These studies are essential to better understand the host-microbe interactions, considering that bacteria and fungi from the microbiota may become pathogenic, under specific circumstances, including the occurrence of natural and anthropogenic stressors in the environment (HERNÁNDEZ-GÓMEZ et al., 2020).

In this context, several fungal diseases in reptiles and amphibians have been described, such as gastrointestinal and pulmonary candidiasis in turtles and Batrachochytrium dendrobatidis infections in amphibians, which are responsible for the population decline of several species (KOLBY et al., 2015; BOSCH et al., 2017). However, studies on the fungal microbiota of these animals are limited (BENITES et al., 2013; BRILHANTE et al., 2015a).

Fungal pathogenicity is associated with the production of virulence factors, such as phospholipases and proteases, as well as biofilm formation. Many of these factors have already been described in yeasts from other animal species (SIDRIM et al., 2016; ROCHA et al., 2017). In addition to these virulence factors, decreased susceptibility to fluconazole, itraconazole and amphotericin B has also been described among yeasts from different animal species, highlighting the importance of evaluating the antifungal susceptibility of animal isolates (BENITES et al., 2013; BRILHANTE et al., 2015a).

This study identified yeasts from freeranging reptiles and amphibians from the Caatinga biome. Afterwards, phospholipase and protease production and biofilm formation by these fungi were evaluated, as well as their antifungal susceptibility in planktonic and biofilm growth. Finally, the pathogenicity of $C$. famata in Caenorhabditis elegans infection model was also investigated.

\section{MATERIALS AND METHODS}

\section{Strains}

The yeasts of this study are part of the fungal collection of the Specialized Medical Mycology Center (CEMM) of Federal University of Ceará (UFC). The genera Candida, Cryptococcus and Rhodotorula were included. They were recovered from the oral cavity and cloaca of free-ranging reptiles and amphibians, and the skin surface of amphibians. Samples were collected from seven reptile species (Lygophis dilepis, Boa constrictor, Micrurus ibiboboca, Psomorphis jeobetis, Iguana iguana and Tropidurus hispidus) and six amphibian species (Rhinella granulosa, Rhinella jimi, Leptodactylus latrans, Leptodactylus vastus, Leptodactylus sp. and Pithecopus nordetinus). This study was carried out under authorization of the Chico Mendes Institute of Biodiversity (ICMBio) under protocol number SISBIO-51820-1.

\section{Phenotypic and molecular identification}

Yeasts were grown on Sabouraud agar supplemented with chloramphenicol, and, after 48 hours, colonies suggestive of Candida were seeded on CHROMagar Candida ${ }^{\circledR}$ to verify their purity. The yeasts were submitted to the following biochemical tests: urease production on Christensen's urea agar; carbon and nitrogen assimilation. The yeast micromorphology was then evaluated by Dalmau slide culture on cornmeal-Tween-80 agar (DE HOOG et al., 2000; KURTZMAN et al., 2010).

C. famata and C. parapsilosis colonies were purified on CHROMagar Candida ${ }^{\circledR}$ and grown on YEPD agar (1\% yeast extract, $2 \%$ dextrose, $2 \%$ peptone) and $C$. neoformans was grown on potato dextrose agar. After 48 hour, an inoculum was prepared from each sample in sterile milli-Q water and submitted to DNA extraction. The genetic material extraction was done with the High Pure PCR Template Preparation kit (Roche Applied Science kit, Germany) (CORDEIRO et al., 2018).

The method of TAVANTI et al. (2005) was used for molecular identification of the cryptic species of the $C$. parapsilosis complex. The amplification of the SADH gene (5'-GTTGATGCTTTGGATTGT-3') was carried out by polymerase chain reaction (PCR). The products of this PCR were digested by the enzyme BanI (TermoLab) for up to $16 \mathrm{~h}$ at $37^{\circ} \mathrm{C}$. Afterwards, DNA products were analyzed by electrophoresis in $2 \%$ agarose gel to visualize the obtained digestion patterns and identify the strains according to the number and size of the DNA bands (CORDEIRO et al., 2018).

C. famata complex was identified according to FENG et al. (2014), by $P C R$ amplification using the primers ITS $2 F$ (5'-GATGTATTAGGTAGGTTTATCCAACTCGT-3') and 26SR (5'-TCATTTCAACCCCAATACCTC-3'). Afterwards, the amplicon was digested with $\mathrm{BsaHI}$ and $\mathrm{XbaI}$, at $37{ }^{\circ} \mathrm{C}$, for up to 16 hours. Finally, the digestion products were submitted to agarose gel electrophoresis. C. famata presents three DNA bands (447 bp, 375 bp and $290 \mathrm{bp}$ ), Debaryomyces nepalensis four bands (447 bp, 375 bp, 214 bp and 76 
bp) and C. palmioleopbhila two bands (660 bp and 446 bp) (BRILHANTE et al., 2016a).

C. neoformans was identified according to the methodology described by VELEGRAKI et al. (2001) by the restriction fragment length polymorphism (RFLP) of the amplicon of the primers for the gene URA5 (forward: 5'-ACGGTGAGGGCGGTACTATG-3'; reverse: 5' - AAGACCTCTGAACACCGTAC-3').C. neoformans complex genotypes were identified based on the obtained digestion pattern with the $A l u \mathrm{I}$ restriction enzyme at $37{ }^{\circ} \mathrm{C}$, for up to 16 hours. Digestion products were submitted to agarose gel electrophoresis and restriction patterns were analyzed.

\section{Phospholipase and protease production assay}

The test was performed based on the method described by SIDRIM et al. (2010). Egg yolk agar medium, prepared with $2 \%$ Sabouraud dextrose agar, supplemented with $1 \mathrm{~mol} / \mathrm{L}$ of sodium chloride, $0.05 \mathrm{~mol} / \mathrm{L}$ of calcium chloride and $8 \%$ sterile egg yolk emulsion, was used. The egg yolk emulsion was preheated to $40{ }^{\circ} \mathrm{C}$ in a water bath and then incorporated into the sterile medium. After preparation, the medium was distributed into Petri dishes $(90 \mathrm{~mm})$, forming a $4 \mathrm{~mm}$ layer. Thus, a fungal inocula at a turbidity of 5 on McFarland scale were prepared in $0.9 \%$ sterile saline solution, from yeast colonies with 24 to 72 hours of growth. Then, $10 \mu \mathrm{L}$ of the inoculum were added to sterile filter paper disks $(5 \mathrm{~mm})$ and placed on the surface of the agar. Finally, the plates were incubated for seven days, with daily observation, and reading was based on the measurement of the precipitation zone (opaque halo) around the yeast colony. Phospholipase activity was expressed as $\mathrm{PHz}$, which represents the ratio between colony diameter and precipitation zone diameter (PRICE at al., 1982). When $\mathrm{PHz}=1$, the isolate was negative for the production of extracellular phospholipases, but if $\mathrm{PHz}<1$, the isolate was positive for phospholipase production, where $\mathrm{PHz}>0.64$ indicates weak enzymatic activity, while $\mathrm{PHz}<0.64$ indicates strong enzymatic production. C. albicans ATCC 10231 was used as positive control for phospholipase production.

Protease production was evaluated according to CORDEIRO et al. (2015). For this purpose, bovine serum albumin agar (BSA; Sigma, USA) at $\mathrm{pH} 3.5$ was used. For each tested yeast, fungal inoculum in saline $(0.9 \%$ ) was adjusted to 5 on McFarland scale, after which $10 \mu \mathrm{L}$ of the inoculum were added to sterile paper discs and transferred to the surface of the BSA agar. Plates were incubated at $35^{\circ} \mathrm{C}$, for 5 days. The proteolytic activity was given by PRz, defined as the ratio between the diameter of the yeast colony and total diameter (colony plus proteolysis zone). Thus, $\mathrm{PRz}<1$ indicates the presence of protease activity, while $\mathrm{PRz}=1$ indicates the absence of enzymatic activity. C. albicans strain ATCC 10231 was used as positive control for protease production.

\section{Biofilm formation}

The method described by CORDEIRO et al. (2015) was used for biofilm production. A total of 29 isolates (Candida spp., C. neoformans and Rhodotorula rubra) were used in this test. Yeast cells were resuspended in RPMI 1640 broth (Sigma, USA) and the suspension was adjusted to the concentration of $1 \times 10^{6}$ cells $/ \mathrm{mL}$. Subsequently, $200 \mu \mathrm{L}$ of the inoculum were transferred to 96-well flat-bottomed polystyrene plates, which were incubated at $35{ }^{\circ} \mathrm{C}$ for 48 hours. Wells containing only culture medium without inoculum were used as negative control. The whole experiment was carried out in triplicate. After the incubation, the supernatant was carefully aspirated, and the wells were washed twice with PBS-Tween 20 $(0.05 \%)$. Subsequently, the wells were washed with $100 \mu \mathrm{L}$ of $100 \%$ methanol and the supernatant was aspirated. After drying, $100 \mu \mathrm{L}$ of $0.3 \%$ crystal violet was added to each well. After 20 minutes, the dye solution was aspirated, and the wells were washed twice with sterile distilled water. Then, $150 \mu \mathrm{L}$ of a $33 \%$ acetic acid solution was added to the wells and left for 30 seconds. The volume was then transferred to a new 96-well plate, which was read immediately using a spectrophotometer at $590 \mathrm{~nm}$ to obtain optical density (OD) values. The cutoff values (ODc) for the biofilm formation assay were defined as three standard deviations above the mean OD of the negative control. Strains were classified as non-biofilm producers $(\mathrm{OD} \leq \mathrm{ODc})$, weak producers $(\mathrm{ODc}<\mathrm{OD} \leq 2 \mathrm{xODc})$, moderate producers $(2 \mathrm{xODc}<\mathrm{OD} \leq 4 \mathrm{xODc})$ or strong producers $(\mathrm{OD}>4 \mathrm{xODc})$.

\section{Planktonic antifungal susceptibility assay}

To evaluate the antifungal susceptibility of yeasts (Candida spp., C. neoformans and R. rubra; $\mathrm{n}=29$ ) in planktonic growth, the broth microdilution assay standardized by the Clinical Laboratory Standards Institute, document M27-A3 was applied (CLSI, 2008). For this purpose, RPMI 1640 broth was used. The antifungals used were fluconazole (FLC, 0.125-64 $\mu \mathrm{g} / \mathrm{mL}$; Sigma Chemical Corporation, USA) itraconazole (ITC, 0.03215-16 $\mu \mathrm{g} / \mathrm{mL}$; Sigma Chemical Corporation, USA), voriconazole (VRC, 0.03215-16 $\mu \mathrm{g} / \mathrm{mL}$ Sigma Chemical Corporation, USA) and amphotericin B (AMB, 0.03125-16 $\mu \mathrm{g} /$ 
mL; Sigma Chemical Corporation, USA). Tests were performed in 96-well polypropylene plates. Cells were suspended in saline solution $(0.9 \%)$ until reaching 0.5 turbidity on the McFarland scale. Then the inoculum was diluted $1: 50$ and 1:20 in RPMI 1640 broth to obtain the final inoculum of $0.5-2.5 \times$ $10^{3}$ cells $/ \mathrm{mL}$. The tests were performed in duplicate. The minimum inhibitory concentration (MIC) was determined as the lowest concentration capable of inhibiting fungal growth by $50 \%$, when compared to the drug-free growth control, and $100 \%$ inhibition for AMB (CLSI, 2008). For quality control of the test, the strains of Candida parapsilosis ATCC 22019 and Candida krusei ATCC 6258 were used.

\section{Antifungal susceptibility assay of the biofilm}

The antifungal susceptibility assay of the biofilm was performed as described by BRILHANTE et al. (2016b), with modifications. For this test, 29 isolates (Candida spp., C. neoformans and R. rubra) were analyzed. Biofilm was formed as described above. After biofilm maturation, the drugs diluted in RPMI were added. Antifungal drugs were tested at concentrations of 2-32 $\mu \mathrm{g} / \mathrm{mL}$ for AMB and 8-128 $\mu \mathrm{g} / \mathrm{mL}$ for ITC. For each tested strain, drug-free wells (growth control) and yeast-free wells (sterility control) were included. After the incubation period (48 $\mathrm{h})$, the culture medium was removed and the wells were washed twice with PBS-Tween 20. Finally, biofilm metabolic activity was quantified using the tetrazolium salt reduction test 2,3-bis (2-methoxy-4nitro-5-sulfophenyl)-2H-tetrazolium-5-carboxanilide (XTT; Sigma Chemical Co., USA). Aliquots of 100 $\mu \mathrm{L}$ of XTT-menadione solution $[0.5 \mathrm{mg} / \mathrm{L}$ XTT and $1 \mu \mathrm{M}$ of menadione (Sigma Chemical Co., USA)], prepared in PBS and filtered through a $0.22 \mu \mathrm{M}$ membrane were incubated in the dark, at $37^{\circ} \mathrm{C}$, for 3 hours. After the incubation period, the XTT solution was transferred to the wells of a new plate, followed by spectrophotometric reading at $492 \mathrm{~nm}$. The sessile minimum inhibitory concentration (SMIC) against mature biofilms was determined as the minimum concentration capable of reducing 50\% (SMIC50) and $90 \%$ (SMIC90) of the biofilm metabolic activity, when compared to the drug-free growth control of the respective strain). Subsequently, biofilm biomass was spectrophotometrically quantified by the crystal violet staining technique, as described above. The assay was performed in triplicate.

\footnotetext{
C. famata pathogenesis against Caenorhabditis elegans

The test was performed according to the protocol established by BRILHANTE et al.
}

(2016b), with modifications. C. famata was the only species included in this assay, as it presented a more representative number of isolates $(n=13)$. Thus, strains of C. famata and L4 stage nematodes were used in this experiment. The nematodes were previously cultured in nematode growth medium (NGM) containing Escherichia coli OP50 as a food source. Yeast strains were grown on BHI agar (Brain Heart Infusion - Himedia ${ }^{\circledR}$ ) medium supplemented with $100 \mu \mathrm{g} / \mathrm{mL}$ of ciprofloxacin, at $35^{\circ} \mathrm{C}$, for up to 72 hours. C. albicans ATCC 10231 was used as a positive pathogenicity control. E. coli OP50 strain was also previously cultured on BHI agar without ciprofloxacin at $30{ }^{\circ} \mathrm{C}$, for 24 hours, and used as a negative pathogenicity control. Subsequently, the nematodes were washed from the plates containing NGM with M9 buffer and transferred to the plates containing the microorganisms. The plates were kept in an incubator at $25{ }^{\circ} \mathrm{C}$ for 2 hours, for the nematodes to feed on the microorganisms. After incubation, three consecutive nematode washes were performed to remove the microorganisms adhered to the worm cuticle. Approximately 50 nematodes were transferred to 6-well cell culture plates containing $1.5 \mathrm{~mL}$ of liquid medium composed of M9 (79\%), BHI broth $(20 \%), 100 \mu \mathrm{g} / \mathrm{mL}$ cholesterol in ethanol and $100 \mu \mathrm{g} / \mathrm{mL}$ of ciprofloxacin. Plates were then incubated at $25{ }^{\circ} \mathrm{C}$ and nematode viability was analyzed after 0, 24, 48, 72 and 96 hours. Thus, animals that had fungal structures growing outwards from the worm pseudocoelom and/or those that did not respond to mechanical stimuli were considered dead. Each nematode considered dead was removed from the well throughout the experiment. At the end of the period, a survival curve was established.

\section{Statistical analysis}

Friedman's test, followed by Dunn's post hoc test, was used to compare biomass and metabolic activity of Candida spp. mature biofilms, after exposure to AMB and ITC, to those of the drugfree growth control. To analyze $C$. famata induced mortality rate of $C$. elegans, Kaplan-Meyer survival curves were constructed and the log-rank and Breslow tests were used. P-values lower that 5\% indicated significant conclusions.

\section{RESULTS}

The microorganisms were identified by morphological and molecular methods, as follows: C. famata (13/29), Candida tropicalis (7/29), C. parapsilosis sensu stricto (3/29), Candida 
metapsilosis (1/29), Candida guilliermondii (1/29), C. neoformans (2/29) and R. rubra (2/29) (Table 1).

Regarding enzymatic production, 16/29 identified yeasts were phospholipases positive, of which $5 / 16$ had strong activity $(\mathrm{PHz}<0.64)$. As for protease activity, 10/29 strains were positive, with PRz ranging from 0.59-0.86 (Table 1).

Concerning planktonic antifungal susceptibility, MIC ranges against $C$. famata complex were $0.03125-2 \mu \mathrm{g} / \mathrm{mL}$ for $\mathrm{AMB}, 0.5-4 \mu \mathrm{g} / \mathrm{mL}$ for FLC, $<0.03125-4 \mu \mathrm{g} / \mathrm{mL}$ for ITC and $<0.03125-0.5$ $\mu \mathrm{g} / \mathrm{mL}$ for VRC (Table 1). MICs against $C$. tropicalis ranged from $0.0625-0.25 \mu \mathrm{g} / \mathrm{mL}$ for $\mathrm{AMB}, 0.5-4 \mu \mathrm{g} /$ $\mathrm{mL}$ for FLC, $0.0625-16 \mu \mathrm{g} / \mathrm{mL}$ for ITC and $0.03125-1$ $\mu \mathrm{g} / \mathrm{mL}$ for VRC. As for the C. parapsilosis complex, the MIC ranges were $0.03125-0.25 \mu \mathrm{g} / \mathrm{mL}$ for $\mathrm{AMB}$, $0.5-4 \mu \mathrm{g} / \mathrm{mL}$ for FLC, $<0.03125-0.0625 \mu \mathrm{g} / \mathrm{mL}$ for ITC and $<0.03125-0.0625 \mu \mathrm{g} / \mathrm{mL}$ for VRC. The

Table 1 - Identification, antifungal susceptibility and virulence factors of yeasts recovered from free-ranging reptiles and amphibians from the Caatinga biome.

\begin{tabular}{|c|c|c|c|c|c|c|c|c|}
\hline \multirow[t]{2}{*}{ Animal Species } & \multirow[t]{2}{*}{ Anatomical site } & \multirow[t]{2}{*}{ Yeast species } & \multicolumn{4}{|c|}{$\begin{array}{c}\text { Minimum Inhibitory Concentration - } \\
\operatorname{MIC}(\mu \mathrm{g} / \mathrm{mL})\end{array}$} & \multicolumn{2}{|c|}{ Exoenzymes } \\
\hline & & & AMB & FLC & ITC & VRC & $\mathrm{PHz}$ & PRz \\
\hline ----------------------. & -----------Snakes & 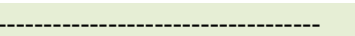 & & & & & & \\
\hline \multirow{2}{*}{ Lygophis dilepis } & \multirow{2}{*}{ Oral cavity } & Candida famata $(1)^{\mathrm{a}}$ & 0.06 & 2 & $4^{*}$ & 0.125 & 0.79 & 1 \\
\hline & & Rhodotorula rubra (1) & 0.5 & $<0.125$ & 0.5 & 8 & 1 & 1 \\
\hline \multirow{2}{*}{ Boa constrictor } & Oral cavity & Candida tropicalis (1) & 0.06 & 4 & $16^{*}$ & 0.06 & 0.89 & 1 \\
\hline & Cloaca & C. tropicalis (1) & 0.06 & 1 & 0.25 & 0.06 & 1 & 0.79 \\
\hline \multirow{3}{*}{$\begin{array}{l}\text { Micrurus } \\
\text { ibiboboca }\end{array}$} & Oral Cavity & C. tropicalis (1) & 0.06 & 1 & 0.06 & 0.06 & 0.76 & 0.95 \\
\hline & \multirow{2}{*}{ Cloaca } & C. tropicalis (1) & 0.06 & 1 & 0.06 & 0.06 & 0.91 & 0.68 \\
\hline & & Cryptococcus neoformans (1) & 2 & 4 & 0.06 & 0.125 & 0.85 & 1 \\
\hline \multirow{2}{*}{$\begin{array}{l}\text { Psomorphis } \\
\text { jeobestis }\end{array}$} & \multirow{2}{*}{ Oral cavity } & Candida metapsilosis (1) & 0.06 & 0.5 & 0.03 & 0.03 & 0.88 & 1 \\
\hline & & C. famata (1) & 0.03 & 0.5 & 0.03 & 0.03 & 0.64 & 1 \\
\hline & ------Lizards- & 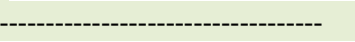 & & & & & & \\
\hline \multirow[t]{2}{*}{ Iguana iguana } & Oral Cavity & $\begin{array}{l}\text { Candida parapsilosis } \\
\text { sensu stricto }(1)\end{array}$ & 0.125 & 0.5 & 0.03 & 0.03 & 0.75 & 0.67 \\
\hline & Cloaca & C. famata (1) & 0.03 & 4 & 0.0625 & $<0.03$ & 0.68 & 1 \\
\hline $\begin{array}{l}\text { Tropidurus } \\
\text { hispidus }\end{array}$ & Cloaca & C. neoformans (1) & 0.5 & 4 & 0.03 & 0.03 & 0.88 & 1 \\
\hline \multicolumn{9}{|c|}{ 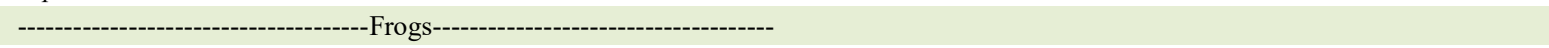 } \\
\hline Leptodactylus sp. & Skin & C. parapsilosis s. s. (1) & 0.03 & 4 & 0.06 & 0.03 & 1 & 0.8 \\
\hline \multirow[t]{2}{*}{$\begin{array}{l}\text { Leptodactylus } \\
\text { latrans }\end{array}$} & \multirow[t]{2}{*}{ Cloaca } & C. famata (3) & 0.125 & 1 & $\begin{array}{l}0.03- \\
0.125\end{array}$ & $\begin{array}{c}0.03- \\
0.06\end{array}$ & $\begin{array}{l}0.86(1) \\
1(2)\end{array}$ & $\begin{array}{c}0.59(1) \\
1(2)\end{array}$ \\
\hline & & C. tropicalis (1) & 0.25 & 1 & 0.5 & 0.03 & 1 & 1 \\
\hline $\begin{array}{l}\text { Leptodactylus } \\
\text { vastus }\end{array}$ & Cloaca & C. tropicalis (1) & 0.25 & 0.5 & $16^{*}$ & 0.03 & 0.37 & 0.86 \\
\hline $\begin{array}{l}\text { Pithecopus } \\
\text { nordestinus }\end{array}$ & Oral cavity & C. famata (1) & 0.03 & 4 & 0.06 & 0.125 & 1 & 1 \\
\hline \multicolumn{9}{|c|}{--------------------------------------'Toads------------------------------------ } \\
\hline $\begin{array}{l}\text { Rhinella } \\
\text { granulosa }\end{array}$ & Skin & C. tropicalis (1) & 0.25 & 2 & $2^{*}$ & 1 & 0.6 & 0.81 \\
\hline \multirow{5}{*}{ Rhinella jimi } & \multirow{2}{*}{ Oral cavity } & C. famata (1) & 0.03 & 1 & 0.03 & 0.03 & 1 & 0.84 \\
\hline & & C. parapsilosis s. s. (1) & 0.25 & 1 & $<0.03$ & $<0.03$ & 1 & 0.75 \\
\hline & \multirow{3}{*}{ Skin } & C. famata (5) & $0.06-2$ & $0.5-2$ & $\begin{array}{l}\leq 0.03- \\
2^{*}\end{array}$ & $\begin{array}{c}\leq 0.03- \\
0.5\end{array}$ & $\begin{array}{c}0.5-0.97 \\
(4) \\
1(1)\end{array}$ & $\begin{array}{l}0.78(1) \\
1(4)\end{array}$ \\
\hline & & Candida guilliermondii (1) & 0.125 & 1 & 0.06 & 0.03 & 1 & 1 \\
\hline & & R. rubra (1) & $<0.03$ & 2 & 1 & 1 & 0.72 & 1 \\
\hline
\end{tabular}

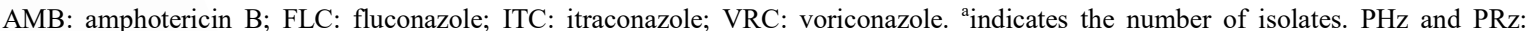
indicate the production of phospholipase and protease, respectively, based on the ratio between the size of the yeast colony and the total diameter (colony and halo). When $\mathrm{PHz}=1$ and $\mathrm{PRz}=1$, the isolate is negative for exoenzyme production. "Resistance. 
obtained MICs against C. guilliermondii were 0.125 $\mu \mathrm{g} / \mathrm{mL}$ for AMB, $1 \mu \mathrm{g} / \mathrm{mL}$ for FLC, $0.0625 \mu \mathrm{g} / \mathrm{mL}$ for ITC and $0.03125 \mu \mathrm{g} / \mathrm{mL}$ for VRC.

As for the non-Candida isolates, MICs against $C$. neoformans were $4 \mu \mathrm{g} / \mathrm{mL}$ for FLC and ranged from $0.5-2 \mu \mathrm{g} / \mathrm{mL}$ for $\mathrm{AMB}, 0.03125-0.0625 \mu \mathrm{g} /$ $\mathrm{mL}$ for ITC and $0.03125-0.125 \mu \mathrm{g} / \mathrm{mL}$ for VRC. Finally, the obtained MICs against $R$. rubra were $<0.03125-0.5$ $\mu \mathrm{g} / \mathrm{mL}$ for AMB, $<0.25-2 \mu \mathrm{g} / \mathrm{mL}$ for FLC, $0.5-1 \mu \mathrm{g} /$ $\mathrm{mL}$ for ITC and 1-8 $\mu \mathrm{g} / \mathrm{mL}$ for VRC (Table 1 ).

All tested strains $(n=29)$ produced biofilms, of which 10/29 were moderate producers and 19/29 were strong producers. Overall, for Candida spp. AMB caused biomass reduction $(\mathrm{P}<0.05)$ starting at $8 \mu \mathrm{g} / \mathrm{mL}$ and decreased $(\mathrm{P}<0.05)$ metabolic activity at all tested concentrations $(2-32 \mu \mathrm{g} / \mathrm{mL})$, while ITC only reduced $(\mathrm{P}<0.05)$ biofilm biomass and metabolic activity at the two highest concentrations (64 and $128 \mu \mathrm{g} / \mathrm{mL}$ ).

Concerning the antifungal susceptibility of mature biofilms of $C$. famata, AMB caused a biomass reduction of $61-71 \%$ and a metabolic activity decrease of $57-90 \%$, and the highest tested concentration (32 $\mu \mathrm{g} / \mathrm{mL}$ ) was defined as the SMIC90. ITC reduced biofilm biomass by $28-47 \%$ and metabolic activity by $7-12 \%$ (Figure 1). Regarding $C$. tropicalis biofilms, AMB reduced their biomass by $20-28 \%$ and metabolic activity by $17-36 \%$. In addition, ITC caused little biomass reduction (2-16\%) and a decrease of $5-18 \%$ in metabolic activity (Figure 1). As for C. parapsilosis complex biofilms, AMB

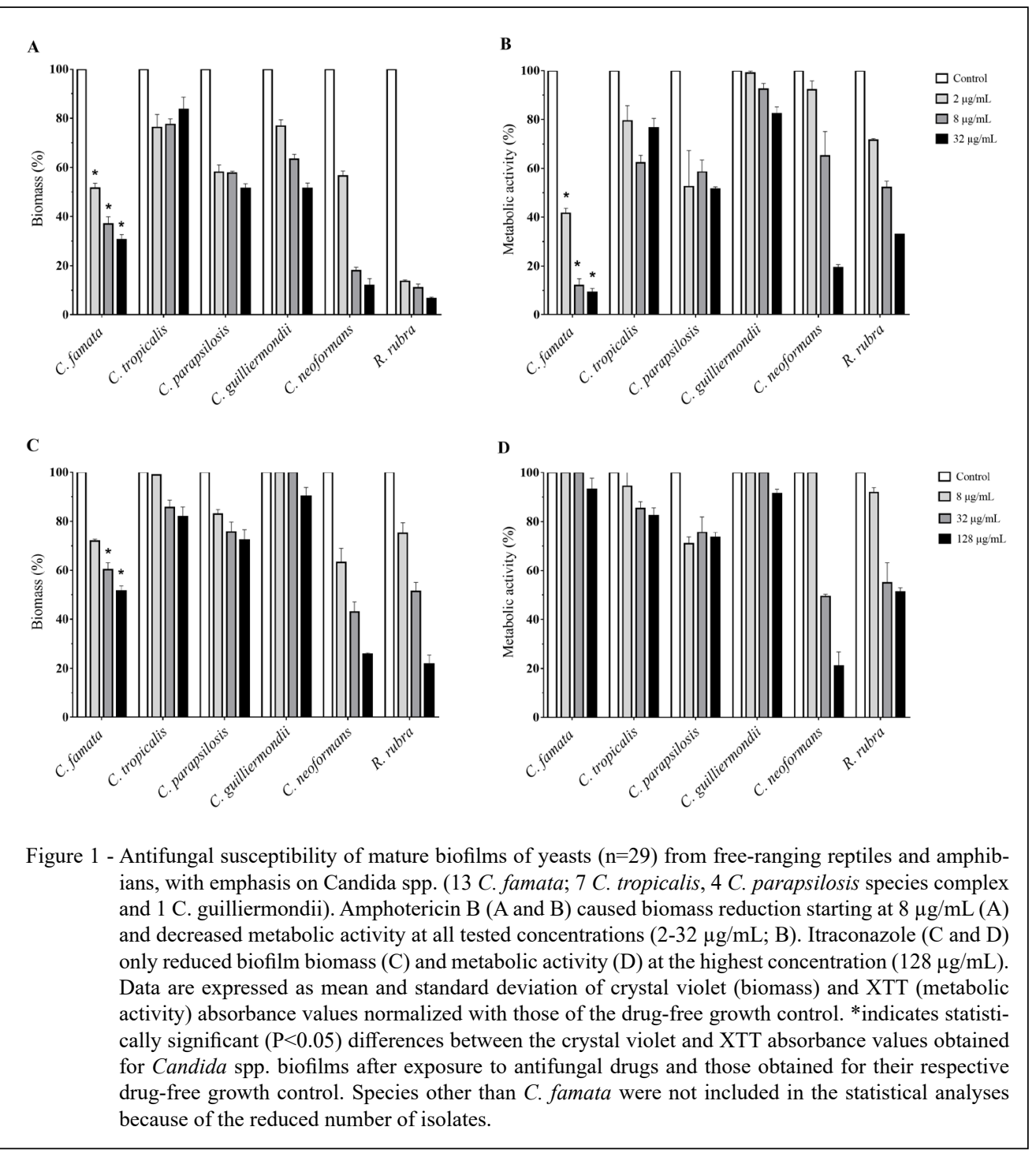

Ciência Rural, v.51, n.7, 2021. 
caused $46-48 \%$ and $37-49 \%$ reduction in biomass and metabolic activity, respectively, while ITC induced $16-25 \%$ biofilm biomass reduction and a decrease of $25-31 \%$ in biofilm metabolic activity (Figure 1). At last, $C$. guilliermondii biofilms presented a maximum decrease in biomass and metabolic activity of $47 \%$ and $16 \%$, respectively, after exposure to AMB. ITC reduced the biomass of these biofilms by $8 \%$ and their metabolic activity by $2-9 \%$ (Figure 1 ).

As for biofilms of $C$. neoformans, AMB caused a biomass decrease of $89-90 \%$ and a reduction in metabolic activity of $6-82 \%$. ITC reduced the biomass by $33-73 \%$ and the biofilm metabolic activity by $31-75 \%$ (SMIC50 $=32 \mu \mathrm{g} / \mathrm{mL}$ ). Moreover, $R$. rubra biofilms suffered $86-94 \%$ decrease in biomass and 28$67 \%$ reduction in metabolic activity, after exposure to AMB. ITC reduced the biomass of these biofilms by $25-70 \%$ and their metabolic activity by $8-49 \%$.

Finally, $C$. famata strains induced $C$. elegans death, reducing worm viability by up to $60 \%$, after 48 hours of exposure. The mortality rate induced by this yeast species was greater $(\mathrm{P}<0.0001)$ than that obtained for both negative (E. coli OP50) and positive (C. albicans ATCC 102301) controls of pathogenicity (Figure 2).

\section{DISCUSSION}

The data on the microbiota of reptiles and amphibians are scarce. The present study identified yeasts from reptile and amphibian microbiota. Candida was the most frequently isolated genus, with C. famata and C. tropicalis as the most prevalent species. C. parapsilosis complex and C. guilliermondii also were identified. Studies on animal microbiota have shown the genus Candida as the most prevalent yeasts (BENITES et al., 2013; BRILHANTE et al., 2015a; SIDRIM et al., 2016). Similar to our findings, other authors have also described $C$. famata and $C$. tropicalis in reptiles, such as turtles (BRILHANTE et al., 2015a) and tortoises (BENITES et al., 2013).

Besides the genus Candida, the species $C$. neoformans and $R$. rubra were also identified. It is important to mention that the genus Cryptococcus has not been commonly reported in reptiles and amphibians. However, MCNAMARA et al. (1994) isolated $C$. neoformans causing infection in a captive snake (Eunectes murinus).

Despite being present in the microbiota, these yeasts produce several virulence factors and are commonly associated with infections, thus, knowledge on animal microbiota is relevant for the understanding of several biological characteristics. In this study, C. famata, C. tropicalis and C.parapsilosis sensu stricto produced both phospholipases and proteases, but only the two former species presented strong phospholipase-producing isolates $(\mathrm{Pz}<0.64)$. Production of virulence factors such as proteases and phospholipases contribute to Candida pathogenicity and they are well elucidated for $C$. albicans

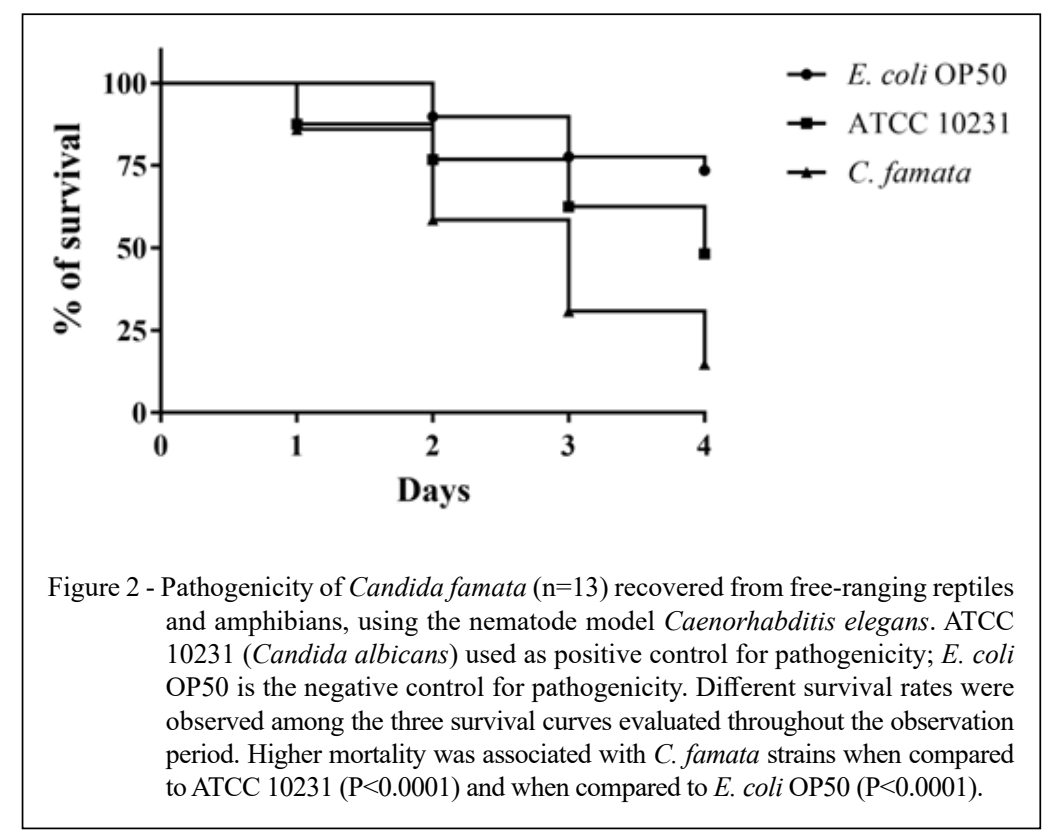

Ciência Rural, v.51, n.7, 2021. 
(BERMAN \& SUDBERY, 2002; FANNING \& MITCHELL, 2012).

Concerning the antifungal susceptibility assay, high ITC MICs $(\geq 2 \mu \mathrm{g} / \mathrm{mL})$ were observed against $C$. famata $(2 / 13)$ and $C$. tropicalis $(3 / 7)$. This finding is relevant because the tested animals were free-ranging wild animals that had never been treated with antifungal drugs, suggesting the presence of antifungal selective pressure in the environment, possibly due to the use of azoles in agricultural practices. It is important to emphasize that high azole MICs have been reported against yeasts from the microbiota of several animal species (BRILHANTE et al., 2015b; 2016a; CORDEIRO et al., 2015; SIDRIM et al., 2016). Moreover, it is important to emphasize that high azole MICs against $C$. tropicalis are commonly reported (KOTHAVADE et al., 2010; CORDEIRO et al., 2015). As for C. parapsilosis species complex, the obtained isolates were susceptible to the tested antifungals, corroborating previous reports (BRILHANTE et al., 2018).

AMB presented high MIC against one isolate of $C$. neoformans $(2 \mu \mathrm{g} / \mathrm{mL})$, while azole antifungals (FLC, VRC and ITC) showed low MIC ranges. High AMB MICs are not commonly reported in the literature, but some authors have reported MIC ranges of $0.25-1 \mu \mathrm{g} / \mathrm{mL}$ (PERFECT et al., 1996) and $0.06-0.12 \mu \mathrm{g} / \mathrm{mL}$ (GAGO et al., 2017) against $C$. neoformans. Moreover, VRC MICs against $R$. rubra were high, as they were comparable to MICs obtained against clinical Rhodotorula isolates (PRENEY et al., 2003; SERENA et al., 2004).

As for mature biofilm antifungal susceptibility, $C$. famata biofilms were more susceptible to AMB (SMIC90 $=32 \mu \mathrm{g} / \mathrm{mL}$ ) than ITC, whose SMIC50 was not reported. C. famata biofilm susceptibility is poorly investigated. C. famata complex species are commonly found in natural substrates and as part of the microbiota of some animal species, including humans, but it is considered an atypical human pathogen (BENITES et al., 2013; BRILHANTE et al., 2017).

C. tropicalis mature biofilms showed low antifungal susceptibility, against which SMIC90 or SMIC50 values were not found. C. tropicalis resistance in animal isolates has been reported (CORDEIRO et al., 2015; BRILHANTE et al., 2016a), which is associated with overexpression of efflux pump-related genes (BIZERRA et al., 2008), which are usually overexpressed when fungi are grown in their biofilm forms. AMB was also more effective than ITC against $C$. parapsilosis species complex and C. guilliermondii biofilms, but SMIC90 values were not reported. Concerning $C$. neoformans and $R$. rubra biofilms, both AMB and ITC presented inhibitory activity, reducing their biomass and metabolic activity.

As for the pathogenicity of $C$. famata using C. elegans infection model, high mortality rates were observed 48 and 96 hours after exposing the worms to this yeast species. Similar results have been observed for other Candida species (BRILHANTE et al., 2016b), which highlights the pathogenic potential of this yeast genus. These values were significantly higher than those for the negative pathogenicity control, demonstrating the pathogenic potential of C. famata, which is possibly associated with the expression and production of the virulence factors, observed in this study.

In summary, the microbiota of reptiles and amphibians contains yeasts able to produce important virulence factors, such as hydrolytic enzymes and biofilms. In addition, itraconazole resistance was observed among $C$. famata and $C$. tropicalis. Finally, C. famata strains increased the mortality rates of C. elegans.

\section{ACKNOWLEDGEMENTS}

This research was financed by the Conselho Nacional de Desenvolvimento Científico e Tecnológico (CNPq), Brasil Finance code 428737/2018-8.

\section{DECLARATION OF CONFLICT OF INTEREST}

The authors declare no conflict of interest. The founding sponsors had no role in the design of the study; in the collection, analyses, or interpretation of data; in the writing of the manuscript, and in the decision to publish the results.

\section{AUTHORS' CONTRIBUTIONS}

MFGR, MPAN, JJCS and RSNB conceived and designed experiments. RVGF, JSO, MGR and GSA performed the experiments, RVGF, RAC and JSO carried out the lab analyses. WAPN performed statistical analyses of experimental data. RVGF, MFGR and DSCMCB prepared the draft of the manuscript. All authors critically revised the manuscript and approved of the final version.

\section{REFERENCES}

BENITES, N. R. et al. Bacterial And Fungal Microflora Present in The Cloacae of Domestically Kept Red-Footed Tortoises (Geochelone carbonaria). Veterinária e Zootecnia, 2013. v.20, n.1, p.102-110. Available from: <https://www.researchgate.net/ publication/262637891_Microbiota_Bacteriana_e_Fungica_ Presentes na Cloaca de Jabutis-Piranga Geochelone carbonaria_Criados_em_Domicilio_Bacterial_And_Fungal_ 
Microflora_Present_in_The_Cloacae_of_Domestically_Kept Red-Footed $>$. Accessed: Mar. 04, 2020

BERMAN, J.; SUDBERY, P. E. Candida albicans: A molecular revolution built on lessons from budding yeast. Nature Reviews Genetics, 1 dez. 2002. v.3, n.12, p.918-930. Available from: $<$ https://www.nature.com/articles/nrg948>. Accessed: Mar. 04, 2020. doi: $10.1038 / \mathrm{nrg} 948$

BIZERRA, F. C. et al. Characteristics of biofilm formation by Candida tropicalis and antifungal resistance. FEMS yeast research, 2008. v.8, n.3, p.442-50. Available from: <https:// academic.oup.com/femsyr/article/8/3/442/599186>. Accessed: Mar. 04, 2020. doi: 10.1111/j.1567-1364.2007.00347.x.

BORGES-LEITE, M. J.; RODRIGUES, J. F. M.; BORGESNOJOSA, D. M. Herpetofauna of a coastal region of northeastern Brazil. Herpetology Notes, 2014. v.7, p.405-413.

BOSCH, R. A. et al. First Reports of Tadpole Mouthpart Anomalies in a Cuban Toad (Anura: Bufonidae: Peltophryne). Herpetological Review, 2017. v.48, n.1, p.58-62.

BRILHANTE, R. S. N.; RODRIGUES, P. H. De A.; et al. Evidence of fluconazole-resistant Candida species in tortoises and sea turtles. Mycopathologia, 2015. v.180, n.5-6, p.421426. Available from: $<$ https://link.springer.com/article/10.1007/ s11046-015-9923-0>. Accessed: Apr. 25, 2020. doi: 10.1007/ s11046-015-9923-0.

SILVA, S. T. C.; et al. Emergence of azole-resistant Candida albicans in small ruminants. Mycopathologia, 2015. v.180, n.3-4, p.277-280. Available from: <https://link.springer. com/article/10.1007\%2Fs11046-015-9888-z>. Accessed: May, 20, 2020. doi: $10.1007 / \mathrm{s} 11046-015-9888-\mathrm{z}$.

; MAIA-JÚNIOR, J. E.; et al. Yeasts from the microbiota of bats: A focus on the identification and antimicrobial susceptibility of cryptic species of Candida. Journal of Medical Microbiology, 2016. v.65, n.10, p.1225-1228. Available from: <https://www. microbiologyresearch.org/content/journal/jmm/10.1099/ jmm.0.000340\#tab2>. Accessed: Mar. 04, 2020. doi: 10.1099/ jmm.0.000340.

OLIVEIRA, J. S.; et al. Candida tropicalis from veterinary and human sources shows similar in vitro hemolytic activity, antifungal biofilm susceptibility and pathogenesis against Caenorhabditis elegans. Veterinary Microbiology, 2016. v.192, p.213-219. Available from: <https://www.sciencedirect.com/ science/article/pii/S0378113516301997?via\%3Dihub>. Accessed: May, 20, 2020. doi: 10.1016/j.vetmic.2016.07.022.

et al. Yeasts From Scarlet Ibises (Eudocimus ruber): A Focus on Monitoring the Antifungal Susceptibility of Candida famata and Closely Related Species. Medical mycology, 2017. v.55, n.7, p.725-732. Available from: $<$ https://academic.oup.com/ mmy/article/55/7/725/2999704>. Accessed: Mar. 4, 2020. doi: 10.1093/MMY/MYW144.

et al. Antifungal susceptibility and virulence of Candida parapsilosis species complex: An overview of their pathogenic potential. Journal of Medical Microbiology, 1 jul. 2018. v.67, n.7, p.903-914. Available from: $<$ https:// www.microbiologyresearch.org/content/journal/jmm/10.1099/ jmm.0.000756\#tab2>. Accessed: Mar. 4, 2020. doi: 10.1099/ jmm.0.000756.
CARDOSO-BRITO, V. et al. Conjunctival bacterial flora and antimicrobial susceptibility of captive and free-living sea turtles in Brazil. Veterinary ophthalmology, 2019. v.22, n.3, p.246-255. Available from: <https://onlinelibrary.wiley.com/doi/abs/10.1111/ vop.12584>. Accessed: Apr. 15, 2020. doi: 10.1111/vop.12584.

CLSI. Reference method for broth dilution antifungal susceptibility testing of yeasts: approved standard - third edition. M27-A3. ed. Wayne, PA: Clinical and Laboratory Standards Institute, 2008.

CORDEIRO, R. De A. et al. Candida tropicalis isolates obtained from veterinary sources show resistance to azoles and produce virulence factors. Medical mycology, 2015. v.53, n.2, p.145-152. Available from: <https://academic.oup.com/mmy/ article/53/2/145/2812401>. Accessed: Feb. 15, 2020. doi: 10.1093/ $\mathrm{mmy} / \mathrm{myu} 081$.

et al. Phenotype-driven strategies for screening Candida parapsilosis complex for molecular identification. Brazilian Journal of Microbiology, 2018. v.49, p.193-198. Available from: $<$ https://www.ncbi.nlm.nih.gov/pmc/articles/PMC6328843/>. Accessed: Mar. 04, 2020. doi: 10.1016/j.bjm.2017.11.004.

FANNING, S.; MITCHell, A. P. Fungal biofilms. PLoS pathogens, 2012. v.8, n.4, p.e1002585. Available from: <https:// www.ncbi.nlm.nih.gov/pmc/articles/PMC3320593/>. Accessed: May, 03, 2020. doi: 10.1371/journal.ppat.1002585.

FENG, X. et al. Development of two molecular approaches for differentiation of clinically relevant yeast species closely related to Candida guilliermondii and Candida famata. Journal of Clinical Microbiology, 2014. v.52, n.9, p.3190-3195. Available from: $<$ https://jcm.asm.org/content/52/9/3190.long $>$. Accessed: Mar. 04, 2020. doi: 10.1128/JCM.01297-14.

GAGO, S. et al. Molecular identification, antifungal resistance and virulence of Cryptococcus neoformans and Cryptococcus deneoformans isolated in Seville, Spain. Mycoses, 2017. v.60, n.1, p.40-50. Available from: <https://onlinelibrary.wiley.com/doi/ abs/10.1111/myc.12543>. Accessed: Mar. 04, 2020. doi: 10.1111/ myc. 12543 .

HERNÁNDEZ-GÓMEZ, O.; WUERTHNER, V.; HUA, J. Amphibian host and skin microbiota response to a common agricultural antimicrobial and internal parasite. Microbial ecology, 2020. v.79, n.1, p.175-191. Available from: $<$ https://link.springer. com/article/10.1007\%2Fs00248-019-01351-5>. Accessed: May, 04, 2020. doi: 10.1007/s00248-019-01351-5.

HOOG, G. S. DE et al. Atlas of clinical fungi. 2. ed. Baarn: The Nederlands: Centraalbureau voor Schimmslcultures, 2000.

KOLBY, J. E. et al. Presence of amphibian chytrid fungus (Batrachochytrium dendrobatidis) in rainwater suggests aerial dispersal is possible. Aerobiologia, 2015. v.31, n.3, p.411419. Available from: < https://link.springer.com/article/10.1007/ s10453-015-9374-6>. Accessed: Mar. 04, 2020. doi: 10.1007/ s10453-015-9374-6.

KOTHAVADE, R. J. et al. Candida tropicalis: its prevalence, pathogenicity and increasing resistance to fluconazole. Journal of medical microbiology, 2010. v.59, n.8, p.873-880. Available from: <http://jmm.microbiologyresearch.org/pubmed/content/ journal/jmm/10.1099/jmm.0.013227-0>. Accessed: Feb. 02, 2020. doi: $10.1099 / \mathrm{jmm} \cdot 0.013227-0$. 
KURTZMAN, C. P.; FELL, J. W.; BOEKHOUT, T. The yeasts: a taxonomic study. [S.1.]: Elsevier, 2010.

MCNAMARA, T. S. et al. Cryptococcosis in a Common Anaconda (Eunectes murinus). Journal of Zoo and Wildlife Medicine, 1994. v.25, n.1, p.128-132. Available from: <https:// www.jstor.org/stable/20095345>. Accessed: May, 20, 2020. doi: $10.2307 / 20095345$.

NOWAKIEWICZ, A. et al. Aerobic bacterial microbiota isolated from the cloaca of the European pond turtle (Emys orbicularis) in Poland. Journal of wildlife diseases, 2015. v.51, n.1, p.255-259. Available from: <https://meridian.allenpress. $\mathrm{com} / \mathrm{jwd} / \mathrm{article} / 51 / 1 / 255 / 122437 /$ Aerobic-BacterialMicrobiota-Isolated-from-the $>$. Accessed: Feb. 20, 2020. doi: 10.7589/2013-07-157.

PERFECT, J. R. et al. In vitro and in vivo efficacies of the azole SCH56592 against Cryptococcus neoformans. Antimicrobial agents and chemotherapy, 1996. v.40, n.8, p.1910-3. Available from: <https://aac.asm.org/content/40/8/1910.long $>$. Accessed: Feb. 25, 2020. doi: 10.1128/AAC.40.8.1910.

PRENEY, L. et al. Experimental evaluation of antifungal and antiseptic agents against Rhodotorula spp. Mycoses, 2003. v.46, n.11-12, p.492-495. Available from: <https://onlinelibrary. wiley.com/doi/abs/10.1046/j.0933-7407.2003.00930.x? sid=nlm \%3Apubmed>. Accessed: Mar. 04, 2020. doi: 10.1046/j.09337407.2003.00930.x.

PRICE, M. F.; WILKINSON, I. D.; GENTRY, L. O. Plate method for detection of phospholipase activity in Candida albicans. Medical Mycology, 1982. v.20, n.1, p.7-14. Available from: $<$ https://pubmed.ncbi.nlm.nih.gov/7038928/>. Accessed: Sep. 01, 2019. doi: $10.1080 / 00362178285380031$.

ROCHA, M. F. G. et al. Azole resistance in Candida albicans from animals: Highlights on efflux pump activity and gene overexpression. Mycoses, 2017. v.60, n.7, p.462468. Available from: <https://onlinelibrary.wiley.com/doi/ abs/10.1111/myc.12611>. Accessed: 4 mar. 2020. doi: 10.1111/ myc. 12611 .

SERENA, C. et al. In vitro antifungal susceptibilities of uncommon basidiomycetous yeasts. Antimicrobial Agents and Chemotherapy, 2004. v.48, n.7, p.2724-2726. Available from:
$<$ https://aac.asm.org/content/48/7/2724.long > . Accessed: Mar. 04, 2020. doi: 10.1128/AAC.48.7.2724-2726.2004.

SIDRIM, J. J. C. et al. Candida species isolated from the gastrointestinal tract of cockatiels (Nymphicus hollandicus): in vitro antifungal susceptibility profile and phospholipase activity. Veterinary microbiology, 2010. v.145, n.3, p.324-328. Available from: <https://www.sciencedirect.com/science/article/pii/ S0378113510001872?via\%3Dihub>. Accessed: Feb. 01, 2020. doi: 10.1016/j.vetmic.2010.04.006.

et al. Antifungal Resistance and Virulence Among Candida spp. from Captive Amazonian manatees and West Indian Manatees: Potential Impacts on Animal and Environmental Health. EcoHealth, 2016. v.13, n.2, p.328-338. Available from: $<$ https:// link.springer.com/article/10.1007\%2Fs 10393-015-1090-8>. Accessed: May, 05, 2020. doi: 10.1007/s10393-015-1090-8.

SVEDESE,V.M.etal.Fungalmicrobiota fromtheoralmucosaofsympatric lizards from the Brazilian semiarid region. Herpetological Review, 2017. v.48, n.3, p.538-541. Available from: <https://www.researchgate. net/profile/Leonardo_Ribeiro3/publication/319950839_Fungal microbiota_from_the_oral_mucosa_of_sympatric_lizards_from the_Brazilian_semiarid_region/links/ $59 \mathrm{c} 315 \mathrm{ce} 458515 \mathrm{af} 3060 \mathrm{caf} 2 /$ Fungal-microbiota-from-the-oral-mucosa-of-sympatric-lizards-fromthe-Brazilian-semiarid-region.pdf $>$. Accessed: Jun. 20, 2020.

TAVANTI, A. et al. Candida orthopsilosis and Candida metapsilosis spp. nov. to replace Candida parapsilosis groups II and III. Journal of Clinical Microbiology, jan. 2005. v.43, n.1, p.284 292. Available from: $<$ https://jcm.asm.org/content/43/1/284.long $>$. Accessed: Mar. 04, 2020. doi: 10.1128/JCM.43.1.284-292.2005.

VEGA-MANRIQUEZ, D. X. et al. Identification of bacteria present in ulcerative stomatitis lesions of captive sea turtles Chelonia mydas. Veterinary research communications, 2018. v.42, n.3, p.251-254. Available from: <https://link.springer.com/ article/10.1007\%2Fs11259-018-9728-y>. Accessed: Jun. 02, 2020. doi: 10.1007/s11259-018-9728-y.

VELEGRAKI, A. et al. Prospective use of RFLP analysis on amplified Cryptococcus neoformans URA5 gene sequences for rapid identification of varieties and serotypes in clinical samples. Medical Mycology, 2001. v.39, n.5, p.409-417. Available from: $<$ https://academic.oup.com/mmy/article/39/5/409/960965>. Accessed: Mar. 04, 2020. doi: 10.1080/mmy.39.5.409.417. 